SEMinARIUM DOKTORANCKIE Profesora Bohdana Ryszewskiego

Słowa kluczowe: Bohdan Ryszewski, Archiwistyka, archiwum, doktorat, seminarium doktoranckie

Ke y words: Bohdan Ryszewski, Archival sciences, archive, doctoral dissertation, doctoral seminar

Abstract

W artykule przedstawiono historię i funkcjonowanie seminarium doktoranckiego Profesora Bohdana Ryszewskiego na przestrzeni 26 lat wraz z tematami prac doktorskich powstałych w ramach prowadzonej działalności uniwersyteckiej.

Seminarium doktoranckie zostało założone 22 listopada 1986 przez Pana Profesora Bohdana Ryszewskiego po otrzymaniu przez niego stanowiska docenta. Od tamtej pory pracuje nieprzerwanie. Do prowadzenia doktoratów i promowania upoważnia habilitacja, zatem ramy tematyczne seminarium podyktowane są zakresem habilitacji Profesora, warunkując powstawanie prac z zakresu archiwistyki i informacji naukowej.

Założenie i prowadzenie seminarium podyktowane było trzema motywami wynikającymi z przeświadczenia Pana Profesora Ryszewskiego, że: 
1) działalność profesorska wymaga prowadzenia seminarium doktoranckiego,

2) prawdziwe akademickie kształcenie powinno obejmować nie tylko studia magisterskie, podyplomowe, ale także doktoranckie,

3) potrzebami uczniów zgłaszających się do Pana Profesora po Jego habilitacji ${ }^{1}$.

Seminarium ma swój okres prehistoryczny, do którego zalicza się podjęta przez Pana Profesora, na rok przed habilitacją, praca z Panią Aliną Kopiczyńską. Początkowo formalnie jej opiekunem był prof. Mieczysław Wojciechowski, a następnie prof. Sławomir Kalembka, ale tak naprawdę jej pracę prowadził prof. Ryszewski. Na takich samych warunkach, współpracując z profesorem Jackiem Staszewskim, opiekował się też Profesor pracą Pana Marka Zaborowskiego, który miał zrobić monografię pierwszego okresu Archiwum Stanisława Augusta Poniatowskiego. Do Profesora, prowadzącego w tym czasie zajęcia z zakresu nauk pomocniczych bibliotekoznawstwa, zgłosiła się też Pani Ewa Głowacka, asystentka szukająca promotora swojej pracy doktorskiej.

W pismach z 1986 r. Pan Profesor zapraszał do udziału w seminarium osoby zainteresowane współpracą w zakresie badania problemów archiwistyki, informacji naukowej i historii zbiorów bibliotecznych. Odpowiedziało jedynie Archiwum Państwowe w Bydgoszczy. Jego dyrektor dr Janusz Kutta do udziału w seminarium zgłosił troje pracowników: Lidię Wakuluk, Melanię Dereszyńską-Romaniuk oraz Pawła Gawryla ${ }^{2}$, których bardzo wspierał $\mathrm{w}$ podjętych pracach.

Zgodnie z zapowiedzią zawartą w zaproszeniu z 1986 r., na pierwszym seminarium Pani Ewa Głowacka przedstawiła koncepcję i wstępne wyniki pracy nad tematem: Problem funkcji informacyjnych biblioteki uniwersyteckiej. Pierwszy pięcioosobowy skład seminarium tworzyła Alina Kopiczyńska, Lidia Wakuluk, Melania Dereszyńska - Romaniuk, Paweł Gawryl i referująca Ewa Głowacka.

1 B. Ryszewski, Seminarium doktoranckie z archiwistyki, (w:) Archiwa w nowoczesnym spoteczeństwie. Pamiętnik V Powszechnego Zjazdu Archiwistów Polskich, Olsztyn, 6-8 września 2007 r., pod red. Jarosława Porazińskiego i Krzysztofa Stryjkowskiego, Warszawa 2008, s. 431.

2 Pismo nr 140-3 z dn. 23.06.1986 r. dot.: Pawła Gawryla; Pismo nr 140-2 z dn. 23.06.1986 r. dot. Melanii Dereszyńskiej-Romaniuk; Pismo nr 140-1 z dn. 23.06.1986 r. dot. Lidii Wakuluk; 
W następnych latach uzupełniali zespół absolwenci seminarium magisterskiego Pana Profesora oraz innych seminariów, po uprzedniej rozmowie z Profesorem na temat zainteresowań i możliwości badawczych przyszłego doktoranta. Z pięciu pierwszych osób liczba uczestników szybko urosła do dziesięciu, licząc, w okresie szczytowym, przypadającym na lata 90-te XX wieku, 18 doktorantów.

W ciągu 26 lat przewinęło się przez seminarium ponad 50 osób ${ }^{3}$. Zdarzało się, że osoby, które opuściły seminarium, po pewnej przerwie, wracały. Zasada możliwości powrotu na seminarium trwa do dzisiaj. W seminariach uczestniczą wypromowani już doktorzy utrzymujący kontakt z promotorem, którzy przyczyniają się do nadawania zebraniom charakteru posiedzeń naukowych i mobilizują pozostałych uczestników. W okresie istnienia seminarium wypromowanych zostało osiemnastu doktorów, z których troje jest po habilitacji, tj. prof. Ewa Głowacka, prof. Waldemar Chorążyczewski i prof. Krzysztof Syta.

$\mathrm{Na}$ seminarium, w toruńskim okresie funkcjonowania, zostało napisanych dziewięć doktoratów, z których ostatni był kończony w Olsztynie, a broniony na UMK. Z dziewięciu prac osiem powstało z zakresu archiwistyki (Lidii Wakuluk, Aliny Kopiczyńskiej, Melanii Dereszyńskiej-Romaniuk, Włodzimierza Bagieńskiego, Krzysztofa Syty, Waldemara Chorążyczewskiego, Macieja Janika, Wiesława Nowosada), a jedna praca, chronologicznie pierwsza, z informatologii - Ewy Głowackiej.

Z seminarium doktoranckiego założonego w Olsztynie wypromowanych zostało czworo doktorantów (Marzena Świgoń, Anna Żeglińska, Rafał Leśkiewicz i Kinga Lisowska). Pięcioro doktorantów zaczęło pracę w okresie toruńskim, a wypromowanych zostało w okresie olsztyńskim, tj.: Ariusz Małek, ks. Roman Majka, Janusz Pawlak, Maria Śliwińska, Katarzyna Kubicka.

$\mathrm{Z}$ analizy Pana Profesora wynika, iż doktorant mający bardzo dobre warunki pracy nad rozprawą (np. etat na uczelni lub studium doktoranckie) broni się po 4-5 latach; pracujący zawodowo przygotowuje pracę około 6-8 lat. Przerwy w pracy nad rozprawą wydłużają czas jej ukończenia o $30-40 \%{ }^{4}$.

3 W 2009 r. Pan Profesor szacował, iż w ciągu ponad 20 lat przewinęło się ponad 48 osób, zob. Ibidem, s. 432).

4 B. Ryszewski, Seminarium doktoranckie z archiwistyki, (w:) Archiwa w nowoczesnym spoteczeństwie. Pamiętnik V Powszechnego Zjazdu Archiwistów Polskich, Olsztyn, 6-8 września 2007 r., pod red. Jarosława Porazińskiego i Krzysztofa Stryjkowskiego, Warszawa 2008, s. 432-433. 
Wszystkie seminaria, od początku, mają zorganizowaną formę. Spotkania odbywają się co miesiąc, od września do czerwca. Zatem w roku przeprowadzanych jest 10 posiedzeń. Stałe są godziny i miejsce spotkań. Od 22 listopada 1986 r. do października 2012 r., czyli przez 26 lat, odbyło się 260 spotkań. Formuła posiedzeń funkcjonowała jednakowo w okresie toruńskim i olsztyńskim. Na Uniwersytecie Mikołaja Kopernika seminaria odbywały się przez 12 lat, zorganizowanych było 120 spotkań w okresie od 1986 r. do 1998 r., na Uniwersytecie Warmińsko-Mazurskim seminarium istnieje od 1998 r., czyli do października bieżącego roku zorganizowanych zostało 140 spotkań. W Olsztynie początkowo posiedzenia odbywały się w przychylnym zawsze Profesorowi tutejszym Archiwum Państwowym. Zjawiskiem niebywałym, godnym podkreślenia jest, iż pomimo kilku zmian miejsca organizacji seminarium, w ciągu 26-letniej działalności, żadne posiedzenie nie zostało odwołane.

Seminarium przeżywało swoje jubileusze. Pierwszy odbył się w 1996 r. w rocznicę 10-lecia funkcjonowania. Wówczas wypromowanych było pięcioro doktorów, tj. Ewa Głowacka, Lidia Wakuluk, Alina Kopiczyńska, Melania Dereszyńska - Romaniuk i Włodzimierz Bagieński.

W ubiegłym roku odbył się w Archiwum Państwowym w Olsztynie jubileusz 25-lecia istnienia seminarium z udziałem uczestników pierwszego posiedzenia: dr Lidii Wakuluk, dr Aliny Kopiczyńskiej, doktorów, którzy z seminarium wyszli oraz obecnych doktorantów. Swoim udziałem zaszczycili uczniowie oraz osoby blisko związane z Panem Profesorem i archiwistyką rozpatrywaną w aspekcie naukowym i praktycznym. Wszystkich uczestników jubileuszowego seminarium przywitała Pani Anna Karpińska, dyrektor APO. Referaty wygłosili: ks. prof. Kazimierz Łatak, prof. Waldemar Chorążyczewski i dr Anna Żeglińska. Swoimi wspomnieniami podzieliła się dr Lidia Wakuluk, dr Janusz Pawlak, dr Maria Śliwińska, dr Katarzyna Kubicka oraz doktorantka: przed tygodniem obroniona Kinga Lisowska; po czym miała miejsce ciekawa dyskusja z udziałem dr Aliny Kopiczyńskiej i prof. Krzysztofa Narojczyka.

Sposób prowadzenia seminarium Pan Profesor wzoruje na seminarium magisterskim prof. Bronisława Włodarskiego, któremu zawdzięcza opanowanie warsztatu, ale także od którego przejął bardzo wysokie wymagania stawiane uczestnikom. Obowiązuje metoda ciągłej dyskusji, która może zacząć się już od pierwszego wypowiedzianego zdania przez referenta. Każdy uczestnik seminarium, z Profesorem włącznie, ma prawo w każdym momen- 
cie przerwać referowanie i zgłaszać wątpliwości ${ }^{5}$. Tekst bowiem musi być zrozumiały w każdym miejscu. Ponadto Profesor, wbrew pozorom, lubi żywą i swobodną atmosferę nie stosując nigdy oficjalnych protokołów, które jego zdaniem, hamują przebieg seminarium. Seminaria cechuje autentyczna naukowa atmosfera, która przyciąga na seminaria magisterskie najzdolniejszych studentów, a następnie na seminaria wyższego stopnia - doktorantów. Jest ona efektem zajmowania się nie tylko tematem pracy, ale przede wszystkim metodą naukową, naukowym podejściem badawczym.

Trwałość i powodzenie Seminarium zawdzięcza nie tylko dobrej organizacji, ale również charakterystycznej dla Profesora łatwości widzenia od początku całej pracy, która ma dopiero powstać, precyzji w formułowaniu jej tematu i struktury, ale również absolutnemu słuchowi językowemu wrażliwemu na każdą nieścisłość terminologiczną, prawidłowość w stosowaniu metod i technik badawczych ${ }^{6}$. Zawsze w charakterze propozycji, sugestii, wyraża Profesor potrzebę wykonania korekt, uzupełnień, poprawek, wykresów, schematów, planów, map. Tematyka seminaryjna i kolejność referowania planowane są na cały rok. Ustalenie z referującym poszczególnych rozdziałów i terminów ich wykonania wpływa dyscyplinująco, w tym i na doktorantów opierających się przed ukończeniem pracy. Mając na uwadze przedstawione wymagania, Seminarium postrzegane jest jako trudne; uczestnictwo w nim jest sprawą ambicji: „należenia do elitarnej grupy”.

Prócz sprawnej i rygorystycznie traktowanej organizacji, trwałość i powodzenie, zdaniem Pana Profesora, seminarium zawdzięcza również działaniu w oparciu o nową podstawę metodologiczną i nową problematykę badawczą. Jako nową podstawę metodologiczną z zakresu archiwistyki Pan Profesor przyjął procesy archiwotwórcze opisane w Problemach $i$ metodach badawczych archiwistyki (1985). Wszystkie prace z zakresu archiwistyki uwzględniają procesy archiwotwórcze jako podstawę badań, przy czym w każdym przypadku to podejście badawcze jest rozwijane i dostosowywane do konkretnego tematu:

5 Profesor B. Ryszewski na seminarium wypowiedział tylko jedno zdanie, po którym zaczęła się ożywiona dyskusja trwająca do końca spotkania.

6 Wg Aliny Kopiczyńskiej, ,Już dawno doktoranci zauważyli łatwość Profesora widzenia całości mającej dopiero powstać pracy, jej konstrukcji i głównych tez”, cyt. za: A. Kopiczyńska, Sylwetka Pana Profesora Bohdana Ryszewskiego, (w:) Archiwistyka i bibliotekoznawstwo, s. 12. 


\section{AnNA ŻEgLińsKa}

Oto 15 tematów z zakresu archiwistyki:

1) Akta miast Rejencji Bydgoskiej (1815-1919). Procesy archiwotwórcze, Lidia Wakuluk (1992 r.)

2) Akta władz administracji gubernialnej Królestwa Polskiego w latach (1867-1915), Alina Kopiczyńska (1993 r.)

3) Kancelaria Urzędu Wojewódzkiego Pomorskiego w Toruniu w latach (1919-1939), Melania Dereszyńska-Romaniuk (1994 r.)

4) Procesy archiwotwórcze archiwaliów miejskich na przykładzie akt miasta Piaseczna na Mazowszu do 1950 r., Włodzimierz Bagieński (1995)

5) Archiwa hetmanów koronnych, Krzysztof Syta (1997 r.)

6) Prywatne archiwa polityczne w Polsce XVI wieku, Waldemar Chorążyczewski (1997r.)

7) Archiwalia miejskie Łodzi (1945-1950). Procesy archiwotwórcze, Maciej Janik, (1998)

8) Archiwa szlachty Prus Królewskich, Wiesław Nowosad (2001)

9) Kamera Wojny i Domen Departamentu Białostockiego Nowych Prus Wschodnich (1796-1807). Monografia zespołu archiwalnego, Ariusz Małek (2004 r.)

10) Problemy opracowania zasobu archiwów zakonnych w skomputeryzowanych systemach informacyjnych na przykładzie Zgromadzenia Świętego Michała Archanioła, ks. Roman Majka (2006 r.)

11) Zasób archiwalny proweniencji państwowej dotyczący spraw żydowskich w II Rzeczypospolitej, Janusz Pawlak (2006 r.)

12) Archiwum Finckensteinów, Anna Żeglińska (2007 r.)

13) Wojskowy Sąd Rejonowy w Poznaniu (1946-1955). Procesy archiwotwórcze, Rafał Leśkiewicz (2008 r.)

14) Akta miasta Gdańska do 1793 r. Procesy aktotwórcze, Katarzyna Kubicka (2009 r.)

15) Problemy struktury zasobu archiwalnego archiwów diecezjalnych na byłym terytorium zaboru pruskiego, Kinga Lisowska (2012 r.)

Tematy wymienionych prac doktorskich wynikały nie tylko z zainteresowań i możliwości doktoranta, lecz również z naukowych zainteresowań promotora. Prace przygotowywane przez pracowników archiwów (publicznych i kościelnych), uwzględniały w większym stopniu zasób i możliwości badawcze doktorantów. W latach 80-tych, Pan Profesor zaczął fascynować się magnaterią i szlachtą zarażając zainteresowaniem archiwami rodowymi i ro- 
dzinno-majątkowymi swoich uczniów. W efekcie powstał cykl prac z tego zakresu, w okresie toruńskim: Waldemara Chorążyczewskiego nt. Prywatnych archiwów politycznych w Polsce w XVI w., Krzysztofa Syty nt. Archiwów hetmanów koronnych, Wiesława Nowosada o Archiwach szlachty Prus Królewskich, w okresie olsztyńskim: Anny Żeglińskiej o Archiwum Finckensteinów oraz zaawansowana praca Marty Adamskiej nt. Zasobu Archiwum Doenhoffów. Z Pana Profesora nowych ustaleń teoretycznych w zakresie zasady strukturalnej wynikła nowa problematyka badania struktury zasobu archiwalnego podjęta przez Kingę Lisowską w pracy Problemy struktury zasobu archiwalnego archiwów diecezjalnych na bytym terytorium zaboru pruskiego. Prace tak pomyślane mają stanowić weryfikację zasady strukturalnej.

Wszystkie powstałe na seminarium doktoranckim rozprawy z zakresu archiwistyki łączy jednolitość metodologiczna umożliwiająca porozumienie naukowe w ramach seminarium, dzięki czemu osiągnięty przez Pana Profesora rezultat nosi znamiona szkoły naukowej.

Nie zostały zrealizowane w postaci rozpraw doktorskich, zainteresowania Pana Profesora problemami komputeryzacji archiwów, ponieważ, jak twierdzi, nie znalazł dotąd odpowiednio przygotowanych kandydatów.

Widoczny związek tematów z zainteresowaniami promotora mieści się w zakresie habilitacji Profesora. $\mathrm{Z}$ archiwistyki wypromowanych zostało 15 prac, zaś z informatologii 3 prace, tj. Ewy Głowackiej: Problem funkcji informacyjnej biblioteki uniwersyteckiej (1990 r.), Marzeny Świgoń: Wspótczesne bariery informacyjne - podstawy teoretyczne i próba badań $w$ środowisku naukowym (2005 r.) oraz Marii Śliwińskiej: Zarządzanie biblioteka naukowa warunkach wprowadzania nowych technologii (2009 r.).

Doktoraty bronione były na 3 uniwersytetach:

1) trzy na Uniwersytecie Wrocławskim, w związku z uprawnieniami uczelni z zakresu informatologii (Ewa Głowacka, Marzena Świgoń, Maria Śliwińska)

2) osiem na UMK (ostatni w 2001 r., ponieważ zaczęty był w Toruniu),

3) siedem na UWM.

Na UMK pracuje pięcioro uczniów:

1) prof. Ewa Głowacka,

2) dr Maria Śliwińska

3) prof. Waldemar Chorążyczewski,

4) prof. Krzysztof Syta,

5) dr Wiesław Nowosad. 
Na UWM pracują dwie uczennice: dr Marzenia Świgoń i dr Anna Żeglińska.

W archiwach (publicznych i kościelnych) ośmioro doktorów:

1) Lidia Wakuluk,

2) Melania Dereszyńska-Romaniuk,

3) Włodzimierz Bagieński,

4) Maciej Janik,

5) Ariusz Małek

6) ks. Roman Majka

7) Rafał Leśkiewicz,

8) Katarzyna Kubicka,

W innych placówkach troje doktorów:

1) Alina Kopiczyńska,

2) Janusz Pawlak,

3) Kinga Lisowska

Wszyscy uczestnicy seminarium stają się uczniami Profesora, który prowadząc zajęcia seminaryjnie nieprzerwanie przez 26 lat realizuje niezbędną w nauce ciągłość tradycji i pokoleń oraz tworzy relację mistrz-uczniowie prowadzącą do powstania szkoły badawczej.

Seminaria doktoranckie (w odróżnieniu do uczelnianych wykładów czy seminariów magisterskich) są spotkaniami nieformalnymi - dlatego decydującą rolę odgrywa w nich osoba prowadząca seminarium, pozostawiając na dalszym planie związek z określonym uniwersytetem czy zakładem traktowanym jako instytucja. W czasie jubileuszu 25-lecia seminarium Profesor stwierdził iż „właściwie cierpi na rodzaj przymusu prowadzenia seminarium”.

Obecnie trudno nazwać Profesora seminarium: doktoranckim, ponieważ jego uczestnikami są już w znacznej większości wypromowani doktorzy. Uczestniczy lub utrzymuje bliski związek z seminarium ośmioro doktorów: Maria Śliwińska, Marzena Świgoń, Katarzyna Kubicka, Anna Żeglińska, ks. Roman Majka, Janusz Pawlak, Rafał Leśkiewicz, Kinga Lisowska oraz troje doktorantów: Marta Adamska, Wojtek Klas i Anna Bogdanowicz. Ostatni jubileuszowy zjazd zgromadził wszystkich uczestników, w tym doktorów, doktorantów oraz osoby deklarujące przynależność do seminarium i związek z Profesorem. 


\section{Su m m a r y \\ Doctoral seminar of Professor Bohdan Ryszewski}

The article presents the doctoral seminar of Professor Bohdan Ryszewski, its history and functioning over 26 years, with topics of dissertations written as part of the academic work. 